\title{
Normative Action Influence on Performance of Biosocial Projects in Informal Settlements in Nairobi County, Kenya
}

\author{
Njeri Simon Ngacha, Prof.Christopher Mwangi Gakuu, Prof.Kidombo Harriet Jepchumba
}

\begin{abstract}
This study sought to establish Normative action influence on performance of biosocial projects in informal settlements in Nairobi County, Kenya. The objective of this study was to examine the extent to which normative action influence performance of biosocial projects in informal settlements. The variable indicators were: Social influence, Cultural beliefs, Psychological Factors and Social Empowerment. The study was premised on social cognitive theory. This study adopted pragmatism and mixed research approach to examine the normative action influence on performance of biosocial projects while descriptive and correlational research designs were adopted. Quantitative data was collected through structured self-administered questionnaires while qualitative data was collected through interview guides after the research instruments were pilot tested for validity through content related method and reliability through test-retest criterion. A sample size of 183 individuals from 61 biosocial projects were selected from a target sample of 70 biosocial projects in Nairobi County through Gakuu, Kidombo and Keiyoro, 2016 sampling formula $(s=(z / e) 2)$. Quantitative data was computed from structured questionnaires administered to 61 staff members working in the selected biosocial projects and 61 beneficiaries of the biosocial projects besides qualitative in- depth interviews with 61 state and nonstate actors through purposive sampling technique. The statistical tools of analysis that were used for descriptive data were the arithmetic mean and the standard deviation while the statistical tools of analysis that were used for inferential statistics were Pearson's Product Moment Correlation (r) and Stepwise Regression (R2). F-tests were used to test hypotheses in the study. Tests of statistical assumptions were carried out before data analysis to avoid invalidation of statistical analysis. From the data analysis the null hypothesis that stated there is no significance relationship between normative action and performance of biosocial projects in informal settlements in Nairobi County was rejected with $r=0.586, F=40.454$ at $p=$ $0.000<0.01$ and concluded that there is significant relationship between normative action and performance of biosocial projects in informal settlements. In conclusion, there were noted key legislations supporting biosocial projects and biosocial community among them being constitution of Kenya 2010 that prohibits discrimination, The Persons with Disabilities Act, 2003, the act being an all-inclusive law encompassing rehabilitation rights and equal opportunities for people with disabilities. It creates the National Council of Persons with Disabilities as a statutory organ to oversee the welfare of persons with disabilities. The Law also obliges that both public and private sector employer's reserve five percent of jobs for disabled persons. Conversely, there is correspondingly the National Security Act, chapter 258, Laws of Kenya, the law alludes to the benefit for worker incapacitated before the established retirement age and National Social Security Fund Act, 1965 (sessional paper number 5 of 1997), amended in 2001,
\end{abstract}

Published on October 30, 2020

Njeri Simon Ngacha

(corresponding e-mail: snnjeri@ gmail.com) the subject contains a provision which states that mental and physical disabilities shall not be considered as leading to work incapacity.

Index Terms - Normative action, performance of projects, Organizational Politics, Power relations, Politics of Identity.

\section{INTRODUCTION}

There is experienced economic hardship promoting increasingly challenging circumstances at the world level. Where one in three urban dwellers lives in the informal settlements and urban informal settlements growth are outdoing urban population growth in developing counties. Out of a given challenge there emerges an ever increasing demand to have projects to address those confronts [11]. Economic disparities, social cultural and political factors could cause discord amongst discontented factions or segments of the society and on the same annotation.

Knowledge performs a significant normative role in affirmation and action, which is expounded and amalgamated by its more deep-seated normative role in belief. Knowledge has come out as the key focus of belief, this structures the normative code of correctness as well as related code of justification [7]. The approaches to normative action from a theoretical perspective deduces that collective action remains an endeavor to enhance the state of the group positively [8]. Normative role of knowledge is correct to assert, believe and act on a suggestion [2]. Apparently, one of the major key indicators under normative action is social influence.

The drift in human conduct intentionally or unintentionally that a person causes to another is termed as social influence. Social influence is broken down into three key taxonomies which are compliance, obedience and conformity [2]. Compliance may be referred to as a situation in which an individual carries out a task he/she has been asked to do by another. He/she may choose to carry out the task or not. When complying, one can have some alternative but on the other hand in obedience; individuals have faith that they do not have an alternative. Many officials in military as well as commercial managers are mainly focused only in obedience through following laid down procedures within the governance ranks, to some extent they are referred to as disciplined forces.

Conformity is changing how one behaves in order to be like others. It can run extremely deep, as it transforms someone`s faith as well as values to reflect those of their peers

Prof.Christopher Mwangi Gakuu

Prof.Kidombo Harriet Jepchumba 
and admired seniors. The two types of conformity are informational and normative [2]. Informational or social proofing is the human likelihood to have faith that others who are close to them might know more than they do and thus go ahead to making decisions which are guided by what others are doing especially in the event where people lean toward one behavior, decision or purchase or else is when one sees others as a source of information.

Individuals who have disabilities tend to conform themselves in groups or in communion in order to amplify their aspirations as they pursue their day to day life demands. Conformity is subdivided into two kinds, informational influence and normative influence. These two types of social influence are conceptually unique [2]. However, they are interrelated to some extent. Normative influence, is when people or groups conform to each other because they believe they have accurate information, and they are influenced by conforming to each other.

\section{A. Statement of the Problem}

The expansion in the population within the areas considered to be urban, has brought changes in the cities in Africa as well as stretching of city resources. However, reports show that urbanization has come with proliferation of settlement which are not formal, as well as imbalances in income among individuals thus intensifying poverty in cities. According to the outcomes of the Persons with Disabilities Kenya National Survey executed in the year 2007, about $4.6 \%$ of Kenyans encounter some structure of disability, on the same vein, the planning bulletin article on disability mainstreaming in policy and planning argues that unlike poverty which has major differences in urban and rural areas, disability has no major variances in occurrence in the urban or rural areas or by sex but with age dominance upsurges [16].

Individuals who live with disabilities in Kenya are influenced by poverty due to stigma, inadequate education opportunities, limited access to economic opportunities as well as limited access to labor markets. Women who live with disabilities are especially more vulnerable to the violation of the rights and freedoms. They are most often discriminated in accessing resources such as public facilities. In the Act of 2003 created for the people living with disabilities, section two refers to disability as an impairment which is either be physical, sensory or mental tribulations [16]. Within the 2010 constitution of Kenya, Article 260 guides on the characteristics used to define disability that may have a substantial as well as long term influence on the individual's ability to carry out ordinary daily functions [15].

\section{B. Objective of the Study}

To examine the extent to which normative action influence performance of biosocial projects in informal settlements in Nairobi County, Kenya.

\section{Hypothesis of the Study}

This body of knowledge tested the following alternate and null hypotheses:

1. Ha: There is a significant relationship between normative action and performance of biosocial projects in informal settlements in Nairobi County.

2. Ho: There is no significant relationship between normative action and performance of biosocial projects in informal settlements in Nairobi County.

\section{LITERATURE REVIEW}

One of the indicators of normative action in this body of knowledge is social influence, and within it there are several pointers that inform the social influence, among them are conformity, obedience and compliance. Conformity is further broken down into two phenomena, that is information and normative, the two sets are inextricably intertwined to give conformity a strong bearing [3]. An indicator in monitoring and evaluation framework is a sign showing the progress of a situation and when tracked systematically over time it indicates progress or no progress [15].

The other two sets of social influence that will be studied in this body of knowledge to be precise is obedience and compliance which conversely can be attributed with the example of colonialist ventures, and through such perceptions and influence England as an Island nation was capable of fortifying and building an empire of global scale. Conformity is the kind of social influence that occurs when individuals or groups change their attitudes, behaviors or beliefs to match or imitate those of real or imagined people or circumstances [2]. Convictions, concerning the proficiency of groupings to adjust their conduct, have been unearthed to have an effect on emotions and attitudes directed at groups [4].

Another key indicator under normative action in this body of knowledge is Culture; Culture is the system by which people interact, as well as in what manner they validate interactions across values, beliefs, in addition to norms that forms a strong foundation on where groups and individuals derives social strengths, social identity and cohesion in the contemporary society. [3] espouses that someone's knowledge about the surrounding world emanates from the beliefs from their cultural background despite the fact that not the whole thing that is controlled by culture is acceptable. It informs on the way of living and belief system that work cohesively with social influence which a time stretches or influences the social cultural issues in the coexistent setting. As an outcome, and in line with [1], it can be learnt that since it is not able to provide a distinct grouping of human led activities but conceals a complete breadth of social undertakings, culture is not a normative expression but a descriptive expression.

Developing a human from a cultural point of view addresses mainly how individuals lead their lives. As a result, it determines how society live together and allow human freedom of beliefs, thought and expression that subsequently forms the society cultural freedom index that emanates from social cultural development [2]. Factors which determine social integration may comprise of education as well as marriages amongst different communities. Social fragmentation has been treated as acting a key role in hindering the growth of the economy, however, from a theoretical stand point they point social-cultural fragmentation as having an indirect connection in the economic growth as well as the output per capita.

Through keen analysis of social identity [24] reports that, practitioners around the social psychology discipline have of late focused on uncovering the mechanisms driving the collective action. On the other pointer addresses studies 
which have been carried out on social transformation and looks into a wider perspective of both institutional as well as cultural changes which could have taken place in history. Concurring to Jim Denison August, 2018 in his article dubbed 'suffering and hope transforming faith of the late John McCain' he talked about a verse in the holy bible in the book of Roman 5:3-4 that pronounces on rejoicing in the misery knowing that misery produces persistence in addition persistence produces character which in the long run produces hope. Trying to decipher the same statement that was scribbled by St. Paul more than 2000 years, it is easier to connect that there is a close relationship between hope, character and suffering at any given situation and thus the same was not farfetched in this body of knowledge as its core intent was to address biosocial factors through persuasion of hope and compliance on a set of beliefs that shapes character.

\section{A. Theoretical Framework}

This study focused on examining Normative action influence on performance of biosocial projects in informal settlements. Studies should be grounded on a particular theory and thus this body of knowledge was grounded on seven key theories that strived to stitch together the analysis of key variable under interrogation, diffusion theory supported the independent variable political environment and the theory of constraint supported the dependent variable performance of biosocial projects in informal settlements in Nairobi County Kenya so as to offer a comprehensive and continuous stream of knowledge that unfold challenges and opportunities people living with disabilities are faced with in informal settlements.

\section{Social Cognitive Theory}

Social Cognitive Theory is expended in this study to support the fact that individuals are not either autonomous agents or mechanical facilitators of animating surrounding influences. But, they normally contribute causally towards their own motivation. The theory is critical towards the concept of evolving, interactive energy. An account of predictors of individual human reaction should comprise of self-generated impact as a contribution variable.

This body of knowledge mainly focuses on the measures in which individual action applies with the causal and effect framework in project performance. When looking into how human agency operate under this cause and effect framework, the theory of social cognitive holds a central role towards cognitive imagined as well as self -reflective and regulatory processes. The form in which individuals carry out their functions, has been presented in not less than three diverse forms as either autonomous agency, emergent interactive agency and mechanical agency. Conversely, [11] presents a view that individuals act as entirely independent agents whose actions do not relate to other agents with at least some serious advocates.

\section{Theory of Constraints}

This theory supports the Dependent Variable Performance of Biosocial Projects in informal settlement. Theory of constraints presents a constrain that has the ability of curtailing a given system from realizing higher performance in relation to its set goals [7]. The theory is mainly applied in the management of projects so as to facilitate approach to the critical matters which may cause project delays or failures [17], thus this is the major reason for it to be considered a supporting pillar of performance within projects.

\section{B. Conceptual Framework for the Study}

A conceptual framework in this study was used as the model to provide academic direction on the investigated variables correlation so as to make this publication remain gripped and focused on the two key undermentioned variables as per the figure 1 below:

\begin{tabular}{|c|c|}
\hline Independent Variable & Dependent Variable \\
\hline $\begin{array}{l}\text { Normative Action } \\
\text { - Social Influence } \\
\text { - Cultural Beliefs } \\
\text { - Psychological Factors } \\
\text { - Social Empowerment }\end{array}$ & $\begin{array}{l}\text { Performance of biosocial projects in } \\
\text { informal settlements } \\
\text { - Cost/Budget provision } \\
\text { - Time allocation } \\
\text { - Number of staffing } \\
\text { - Monitoring and Evaluation } \\
\text { - Beneficiary satisfaction }\end{array}$ \\
\hline
\end{tabular}

Fig. 1. Normative action influence on Performance of biosocial projects in informal settlement Conceptual Framework.

\section{RESEARCH METhodology}

Descriptive survey design and correlational research design were the research design that were expended in this body of knowledge. a descriptive study is one in which information is collected without changing the environment and can involve a onetime interaction with groups of people well known as cross sectional study or it might follow individuals over time well known as longitudinal study [3]. Sixty-one (61) biosocial projects (Projects working for people with Disabilities in the entire Nairobi County) was the sample size for this study. Sample size for the study was 182 respondents from 61 biosocial projects of which in every project 3 key respondents from each biosocial project

The sample size was calculated using [4] sampling formula $\mathrm{n}=(\mathrm{z} / \mathrm{e}) 2$

\section{$\mathrm{ME}=\mathrm{z}$}

where:

$\mathrm{ME}=$ the desired margin error;

$\mathrm{n}=$ the sample size;

$\mathrm{z}=$ is the $\mathrm{z}$-score a number relating to the degree of confidence you wish to have in the result. $95 \%$ confidence is most frequently used and accepted. The value of $\mathrm{z}$ confidence is 1.96 for $95 \%$ confidence.

$\mathrm{e}=$ the error you are prepared to accept, measured as a proportion of the standard deviation. In this study a margin error of 0.25 was accepted. A researcher can choose any margin error they like but need to specify it and thus in this body of knowledge a margin error of 0.25 will be picked [4]. In this case the degree of confidence adopted will be $95 \%$. Standard deviation will be based on the objectives set by the study being conducted.

\section{FINDINGS AND DISCUSSIONS}

Research designs that were expended in this study were descriptive research design as well as correlational research design in mixed mode research approach where else 
descriptive, inferential in addition to qualitative statistical analysis were conducted simultaneously. In support of research objective, descriptive analysis was done first by testing mean as well as the standard deviation then trailed by inferential analysis through application of Person's Product Moment Correlation.

\section{A. Background Information of the Respondents}

122 questionnaires were administered, out of it 117 were completely filled, while 5 were incomplete in some instances; the response rate was $95.9 \%$ which was worthy for the study in terms of inferences. Correspondingly, 30 to 50 percent response rate is considered reasonable enough for statistical generalizations [24], and thus with the response rate of $95.9 \%$ in this body of knowledge it is thus satisfactory to deduce lessons from the analysis. Gender of the respondents is as shown in Table 4.1

\begin{tabular}{ccc}
\multicolumn{4}{c}{ TABLE 1: GENDER OF THE RESPONDENTS } \\
\hline Gender & Frequency & $\mathbf{( \% )}$ \\
\hline Male & 32 & 27.4 \\
Female & 85 & 72.6 \\
Total & $\mathbf{1 1 7}$ & $\mathbf{1 0 0}$ \\
\hline
\end{tabular}

Results in Table 1 show that the gender distribution of the respondents was good as the government usually recommends a sector to have at least a representation of $30 \%$ of the opposite gender [9].

\section{B. Distribution of respondents by Age}

The age group categorization was done to ascertain proper distribution. There were five categories, that ranged between 20 to 30 years, 30 to 40 years, 40 to 50 years, 50 to 60 years and the first category over 60 years. The distribution is depicted as per the Table 4.2 below:

TABLE 2: AGE OF RESPONDENTS

\begin{tabular}{ccc}
\hline Age & Frequency & Percentage \\
\hline $20-30$ & 18 & $15 \%$ \\
$30-40$ & 33 & $27 \%$ \\
$40-50$ & 22 & $18 \%$ \\
$50-60$ & 5 & $4 \%$ \\
Above 60 & 1 & $1 \%$ \\
Age not reported & 43 & $35 \%$ \\
Total & 122 & $100 \%$ \\
\hline
\end{tabular}

From the Table 2 above, $35 \%$ of the entire sample did not state their age. However, among individuals who reported, the largest age distribution was for those between 30 and 40 years at $27 \%$, then followed by persons who were between 40 and 50 years at $18 \%$, then those between 20 and 30 years at $15 \%$. The least in the category was age above 60 years which was at $1 \%$ an indication that this is ane set that is at the verge of retiring for those working and for the beneficiaries then it can be deduced is the least reached in service provision.

\section{Test for Statistical Assumptions and Analysis of Likert Type of Data}

A number of tests were conducted, the first one was to help in understanding the suitability of the data used in this study for statistical analysis. The tests were: Test for Normality, Multicollinearity, Singularity, Homoscedasticity and Heteroscedasticity. Further, discussion on how type I and type II errors were controlled and the suitability of using the
Likert scale in the study were further attained. The tests are to study the distribution and suitability of the data to make inference tests. This section of the chapter explains how tests of normality and multicollinearity were carried out.

\section{Normality Test}

In order not to make biased or skewed conclusions it is ideal to check if the data being analyzed is normally distributed. The results of the inference tests would be skewed to one side in the event that the data is skewed on or either side. Regression analysis assumes that data has been collected from normal population of which negation of such normally lead to rejection of the data [15]. Rather, the conclusion of the results of the sample may not be generalized to the whole population but could be just in favor of the sample studied. Kolmogorov-Smirnova (KS-test) and Shapiro-wilk (SW-test) normality tests were simultaneously run in order to verify the distribution of the data.

Subsequently, under the Kolmogorov Shapiro-test statistic, we reject the null hypothesis if $\mathrm{p}<0.05$. While testing for normality, the null hypothesis in the study was that the sample population was not normal. In all the variables under investigation, $\mathrm{p}<0.05$ in which case we reject the null hypothesis and conclude that the samples were picked from a normal population. To countercheck the validity of the normality tests from KS-test statistic, Shapiro-Wilk tests (SW-test) were carried out. The $\mathrm{P}$ value in $\mathrm{SW}$-test is denoted as Sig. and it's the last column [26]. KolmogorovSmirnov test statistic (KS-test) establishes if two datasets vary significantly without making any assumption about the distribution of data.

The interpretation of the tests in this body of knowledge observes from the hypotheses that:

Ho: Variable is not normally distributed

Ha: Variable is normally distributed

The results are depicted as per the Table 3 below:

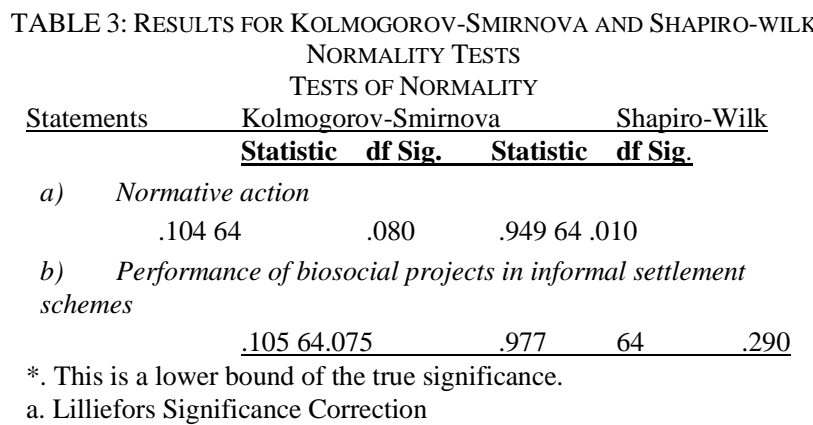

\section{Multicollinearity and Singularity Test}

In this study, multicollinearity was non-existent between the independent. At some point in data analysis, singularity happens when an independent variable is formed from a combination of other independent variables. On the other hand, multicollinearity is checked by analyzing the tolerance values under collinearity to ensure that the assumption is not violated. For instance, 1 - R2 values should be more than 0.1 which implies low multicollinearity. If two variables are perfectly collinear, singularity is said to exist and an exact linear relationship exists between the two predictor variables with a correlation coefficient equal to 1.0 or -1.0 .

The independent variable had a VIF of less than 10 , and the mean VIF of 3.0 was less than 4 an indicator that the 
variable did not have a linear relationship among themselves, particularly there was no multicollinearity. In the event there is multicollinearity the results can have very large standard errors of the beta coefficients hence a higher variability across samples and hence a less chance to represent the population. Multicollinearity may also reduce the contribution of the independent variables making it difficult to assess the individual significance of the predictors.

The study adopted this approach, and the results are as shown in Table 4 below:

TABLE 4: VARIANCE INFLATION FACTOR (VIF) RESULTS INDEPENDENT VARIABLES COLLINEARITY STATISTICS

\begin{tabular}{ccc}
\hline & Tolerance & VIF \\
\hline Normative action & .385 & 2.600 \\
Mean & & 3.0 \\
\hline
\end{tabular}

Dependent Variable: Performance of biosocial projects in informal settlements in Nairobi County.

\section{Tests for Heteroscedasticity and Homoscedasticity-} Levene's test

Homoscedasticity was checked in this body of knowledge by looking at scatterplots between each predictor variable and the dependent variable to ascertain that the cluster of points was approximately the same width in the residual's plots derived by SPSS. Heteroscedasticity in regression analysis can invalidate statistical tests of significance that assume that the modelling errors are uncorrelated and normally distributed and that their variances do not vary with the effects being modelled.

Table 4.5 below stipulates the test of homogeneity of variances.

\begin{tabular}{|c|c|c|c|}
\hline \multirow{2}{*}{ Independent V. } & \multicolumn{2}{|c|}{ Levene Statistic } & \multirow{2}{*}{ P-value } \\
\hline & df1 & df2 & \\
\hline $\begin{array}{c}\text { Normative } \\
\text { action }\end{array}$ & 2.916 & 2350 & .101 \\
\hline
\end{tabular}

The factor in testing homogeneity is performance of projects, while the variable is Normative action. The $p$-value is more than 0.05 implies the variables have met the assumption of homogeneity of variance that states there is equal variance across the range of the study variables.

\section{Control of Type I and Type II Errors}

In this analysis, a correction of low reliability was conducted and obtained a composite Cronbach alpha of 0.944 and this ensured obtaining a true picture of the relationship of the variables and thus minimizing the likelihood of overestimation during multiple regressions.

The factor in testing homogeneity is performance of projects, while the variable is Normative action. The p-value is more than 0.05 implies the variables have met the assumption of homogeneity of variance that states there is equal variance across the range of the study variables.

\section{E. Analysis of Likert Type Data}

When a questionnaire is too lengthy, the response rate is low and the quality of the responses is compromised. In addition, ten objectively constructed items for each research variable in a Likert type scale are sufficient to measure a required construct where mathematical modelling is involved in data analysis thus necessitating the need for coalescing indicators of various variables [6].

\section{F. Overall Descriptive Analysis on Political Environment}

The mean, standard deviation and sample size of respondents to each aspect of each indicator are shown on Table 4.6 below:

TABLE 6: MEAN AND STANDARD DEVIATION OF POLITICAL ENVIRONMENT

\begin{tabular}{cccc}
\hline Normative action & $\mathbf{N}$ & Mean(M) & $\begin{array}{c}\text { Standard } \\
\text { Deviation }\end{array}$ \\
\hline $\begin{array}{c}\text { Social influence- } \\
\text { conformity to social } \\
\text { norms }\end{array}$ & 102 & 3.22 & 1.26 \\
$\begin{array}{c}\text { Social influence- } \\
\text { obedience to social } \\
\text { norms }\end{array}$ & 103 & 3.33 & 1.22 \\
$\begin{array}{c}\text { Social influence- } \\
\text { compliance to social } \\
\text { norms }\end{array}$ & 101 & 3.023 & \\
$\begin{array}{c}\text { Cultural Factors } \\
\text { Psychological factors }\end{array}$ & 103 & 3.77 & 1.32 \\
$\begin{array}{c}\text { Social empowerment } \\
\text { Composite mean }\end{array}$ & 101 & 3.13 & 1.25 \\
\hline
\end{tabular}

Cultural factors and psychological factors had the highest means which were closely equal to 4 an implication of agree, which shows on average the two items of normative action were observed to be important in explaining performance of biosocial projects in informal settlements. In terms of ranking of the other items, social influence-obedience to social norms was higher with a mean of 3.33 , followed by social influenceconformity to social norms with a mean of 3.22 , then social empowerment with a mean of 3.13 and finally social influence-compliance to social norms with a mean of 3.023 . The composite mean was 3.357 which was approximately 3 an indicator of neutral, showing that on average respondents remained neutral on impact of normative action to performance of biosocial projects in informal settlements. Each variable was further analyzed to find out the distribution of the responses, the results were discussed in the preceding subsections.

Theoretical and literature review under this variable points that there is a cause to have faith in that failure to accustom to norms in society produces prejudice, stereotype and stigma. Factors that lead to personality of prejudiced traits are typically inability measure to adjust to social change that is cognitive inflexibility, authoritarianism, stumpy education and customary religiosity [5]. To overcome a negative attitude as an outcome of prejudice, Adjustment to social norms points to repression of prejudices besides distinct emotions leading to various types of action [4]. Fluctuating emotions are ascertained by an extra essential characteristic about whether world and groups can change [25]. Collective action, [25] thoughtful impact in contemporary world, question of how people involve in shared action as the business of developing research in social psychology.

Generally, impact evidence of cash transfer programmes on social empowerment is still inconsistent as it is debated that conditional cash transfers expect children to be taken to health check-ups and school to fortify gender stereotypes of women as accountable for the household, whereas men preserve a role as earners of income. Microfinance correlates to services of finance for those deprived traditional formal banking access. It comprises of micro-credit that stipulates 
provision of loans, micro-savings, insurance in addition to money transfer services. A means of people empowerment to invest in their future and uplift them out of poverty has long been attributed with microfinance interventions [7]. However, there is a developing apprehension that impact of microloans in addition to microcredit on empowerment of poor might not be forthright, in addition highlighting on getting hold of poorest of poor could be inconsistent.

Normative action in this study was grounded on social cognitive theory. The knowledge under it takes part in a role to a model of evolving interaction between individuals and the world surrounding them. The model of shared interconnection, action, affection, cognitive besides other personal aspects and environmental events all function as interrelating causes for an ultimate output in project performance as well as espoused in the project life cycle according to [4]. Any version of the determinants of human action need, therefore, self-generated influences inclusion is a furthering factor to project performance.

Social norms are valuable digressions that leads to exclusion of erosion of social status. Individuality is shaped by group norms and by adapting to the same group norms, thus people living with disabilities as researched in this study have a common determinant that motivates them to organize their social needs around a common objective through biosocial projects

G. Correlation between Normative Action and Performance of Biosocial Projects in Informal Settlement Schemes

In order to establish the direction and magnitude of the relationship between Normative action and performance of biosocial projects a correlation analysis was done. The results of the correlation are shown on Table 7 below:

TABLE 7: CORRELATIONS AMONG VARIABLES PERFORMANCE OF PROJECTS NORMATIVE ACTION

\begin{tabular}{lcc}
\hline Performance of projects & & $.566^{* * *}$ \\
Correlation & 1 & 0.000 \\
Sig. (2-tailed) & & 88 \\
$\mathrm{~N}$ & 106 & \\
Normative action & & $0.566^{* *}$ \\
Correlation & 1 & 0.000 \\
Sig. (2-tailed) & & 97 \\
$\mathrm{~N}$ & 88 & 9 \\
\hline
\end{tabular}

Results above show that, Normative action had a strongest correlation with performance of projects was normative action which had a correlation magnitude of 0.566 . The magnitude implied there existed a positive moderate correlation among normative action and performance of projects.

The results of the correlation are presented on Appendix 1.

Results on Appendix 1 show that apart from cultural beliefs and psychological factors, all the other factors had a positive and moderate correlation with performance of biosocial projects in informal settlements. The magnitude of all the elements which were statistically significant was approximately 0.5 for four of them, indicating a strong correlation. In terms of ranking, the highest was Social Influence-Obedience to social norms with $\mathrm{r}=0.523$, followed by Social Influence-Compliance to social norms with an $r=0.494$, then Social Influence-Conformity to social norms with $\mathrm{r}=0.487$ then finally Social empowerment with $\mathrm{r}=0$. 449.Cultural beliefs and Psychological factors were not statistically significant as they were below 0.2 indicating weak correlation.

\section{H. Inferential Analysis of Influence of Normative Action on Performance of Biosocial Projects in Informal Settlements in Nairobi County Kenya}

In order to establish causality between the independent variable and the dependent variable a regression model was run using the Ordinary Least Square method. The regression was conducted to determine whether there is a statistical relationship between the indicators of each dependent variable and performance of biosocial projects in informal settlements. The analysis of this relationship coincides with testing of the hypothesis.

The results were discussed as per the study hypothesis as follows:

\section{Hypothesis 1}

The hypothesis of this study coincided with the objective. Null hypothesis was:

Ho: There is no significant relationship between normative action and performance of biosocial projects in informal settlements in Nairobi County. To test this hypothesis, a regression model of performance of biosocial projects in informal settlements and normative action was computed. The mathematical model that was used to test the null hypothesis was as follows:

\section{Performance of biosocial projects in informal settlements $=\mathrm{f}$ (normative action)}

$$
\begin{gathered}
\mathrm{Y}=\mathrm{f}(\mathrm{X} 2, \varepsilon) \\
\mathrm{Y}=\beta \mathrm{o}+\beta 2 \mathrm{X} 2+\varepsilon
\end{gathered}
$$

where

$\mathrm{Y}=$ Performance of biosocial projects in informal settlements;

$\mathrm{X} 2=$ Normative action;

$\beta \mathrm{o}=$ Constant term;

$\beta 2=$ Beta Coefficient;

$\varepsilon=$ Error term.

To run the equation, Ordinary Least Square (OLS) method was used to analyze data and results of regression model are displayed in Appendix 2 and Appendix 3.

Appendix 2 presents results of individual elements of normative action while Appendix 3 presents results of normative action as a composite of the individual elements of normative action.

Results from Appendix 2, show that the R coefficient was 0.601 showing there was a strong correlation between normative action and performance of biosocial projects in informal settlements. The adjusted $\mathrm{R}$ squared of 0.313 shows that normative action explained $31.3 \%$ of the variation in Performance of biosocial projects in informal settlements while the rest of the percentage is described by all the other variables not included in normative action model.

In terms of individual elements of normative action, Social influence-Obedience to social norms and cultural beliefs were 
the only elements which were statistically significant, particularly Social influence-Obedience to social norms had a $p$ value of 0.022 which is less than 0.05 and Cultural beliefs had a $p$ value of 0.008 which was less than 0.01 an implication that Social influence-Obedience to social norms was statistically significant at $5 \%$ level of significance and cultural beliefs was significant at $1 \%$ level of significance. In terms of the magnitudes of the Beta coefficients, Social Influence-Obedience to social norms had a higher one of 0.848 while cultural beliefs had 0.816 implying the influence of Social Influence-Obedience to social norms to performance was more than cultural beliefs.

The $\mathrm{F}$ value of 7.617 was statistically significant at $1 \%$ level of significance since $p=0.000$ was less than 0.01 an implication to this was that all the elements of normative action together had a significant relationship with performance of biosocial projects in informal settlements. This relationship existing, the regression model can be transformed to be:

$$
\begin{gathered}
\mathrm{Y}=50.634+0.232 \mathrm{SICF}+0.848 \mathrm{SIO}+0.344 \mathrm{SICC}+ \\
0.816 \mathrm{CB}-0.201 \mathrm{PF}+0.287 \mathrm{SE}
\end{gathered}
$$

where:

SICF = Social Influence-Conformity to social norms;

$\mathrm{SIO}=$ Social Influence-Obedience to social norms;

SICC = Social Influence-Compliance to social norms;

$\mathrm{CB}=$ Cultural beliefs;

$\mathrm{PF}=$ Psychological factors;

$\mathrm{SE}=$ Social empowerment.

The $\mathrm{F}$ value was significant an indicator that there was a significant relationship between normative action and performance of biosocial projects in informal settlements, nonetheless, to ascertain this relationship a composite index of normative action comprising of the elements social influence-conformity to social norms, social influenceobedience to social norms, social influence-compliance to social norms, cultural beliefs, psychological factors and social empowerment was run against performance of biosocial projects in informal settlements.

Results of regression model are depicted on Appendix 3.

On Appendix 3 Beta coefficient of 0.350 for normative action was statistically significant at $1 \%$ level of significance, since the p value 0.000 was less than 0.01 implications that normative action was a significant explanatory variable of performance of biosocial projects in informal settlements.

These results implied that we can reject the null hypothesis that there is no significant statistical relationship between normative action and Performance of biosocial projects in informal settlements. This then means we accept the alternate hypotheses that states there is strong statistical significant relationship between normative action and performance of biosocial projects. As of the literature review. Kursek and Rist (2004) argue that to effectively measure performance monitoring and evaluation ought to be integrated and this then is well explained in this scholarly work as monitoring and evaluation was one of the primary indicators of performance of biosocial projects as a dependent variable.

From the independent variable perspective on the other hand, Social empowerment includes efforts to stop or alleviate threats in the day to day life. The social empowerment models [29] is a multi-dimensional and take in consideration the dimension of value-added decisive analysis of the world, self-concept, participation in organizing change besides improved self-concept. Wallerstein defines empowerment as a social action process that promotes people's participation, communities and governments towards the ultimate goals of collective value addition, quality of life, political efficacy and social justice.

With such interpretation under normative action indicators, it is easier to deduce that the relationship is attributed by coherence of individual's attribute to project performance and existing external factors that affect service delivery. The concept of public empowerment causes confusion to policy makers when considering who to benefit or empower since the term has a bulk of inconsistent definitions depending on different actors, practioners, financiers and politicians. Social influence allows groups and individuals to organize and mobilize themselves towards frequently defined goals of political and social change.

Qualitative data yielded through key informants on conditions that limit PLWD execute their mandates at the household level and also during performance of biosocial projects in informal settlements cited financial constraint to be the major aspect. Several respondents cited financial issues and a strong response from one of the respondents noted that:

"Lack of assistance due to financial constraints, to buy items which can enable them move from one place to another without a challenge"

Though finance being the major set-back, there were a number of challenges that were observed, among them were: "lack of self-confidence as PLWD see themselves as a curse, stigmatization, lack of basic needs at home which may improve their living standards, difficulty in assessing basic facilities like toilets, government funds not reaching them, discrimination and isolation by their community and family members, high poverty levels and health issues like HIV and difficulty in assessing medical assistance".

\section{CONCLUSION AND RECOMMENDATIONS}

The findings in this study are mainly based on the $\mathrm{F}$ statistic which helps to determine if there is a significant relationship between the response variable and the predictive variable. The findings based on the objective and hypothesis that was being tested. The F statistic was judged based on the p-value. In the event the $\mathrm{p}$ value was less than 0.05 , it was an implication that the F statistic was statistically significant a further implication that the independent variable statistically explained the dependent variable.

The objective of this scholarly work was to examine the extent to which normative action influence performance of biosocial projects in informal settlements in Nairobi County, Kenya. The null hypothesis tested was; there is no significant relationship between normative action and performance of biosocial projects in informal settlements in Nairobi County, Kenya. The results were $\mathrm{F}=40.454, \mathrm{P}=0.000<0.05, \mathrm{r}=0.586$, Adjusted R2 $=0.312$. Correlation coefficient was positive and strongly high implying there was a strong correlation between normative action and performance of projects. F statistic was statistically significant implying we reject the null hypothesis and conclude that there is a significant relationship between 
normative action and performance of biosocial projects in informal settlements in Nairobi County.

The study points out that there is a need for accountability of people in higher positions on service delivery. Particularly having leaders or project managers who are transparent during implementation of biosocial projects. This will have an effect on increase of job opportunities to people living with disabilities. In order to sustain it the study recommends that there is a need to increase in numbers of centers that care for people living with disabilities is also recommended and in addition terms of business opportunities and representation given to people living with disabilities should be fair, equal and without bias.

\section{A. Summary of the Test Hypothesis}

The objective of the study was to examine the extent to which normative action influence performance of biosocial projects in informal settlements in Nairobi County, Kenya.
Normative action as an independent variable was defined in terms of the following indicators: Social influenceconformity to social norms, social influence-obedience to social norms, social influence-compliance to social norms, cultural beliefs, Psychological factors and Social empowerment. Descriptive statistics showed that cultural factors had the highest mean followed by psychological factors, then Social influence-obedience to social norms followed by social influence-conformity to social norms, then social empowerment and finally social influence-compliance to social norms. In running the regression model, the most significant variables were cultural beliefs and social influence obedience to social norms. Generally, however as a composite of all these variables, normative action was observed to be an important explanatory variable for performance of projects steering to rejection of the null hypothesis.

APPENDIX

Appendix 1: Correlation between Normative action and performance of biosocial projects in informal settlements

\begin{tabular}{|c|c|c|c|c|c|c|c|}
\hline & & $\begin{array}{c}\text { Social influence- } \\
\text { Conformity to social } \\
\text { norms }\end{array}$ & $\begin{array}{c}\text { Social influence- } \\
\text { Obedience to social } \\
\text { norms }\end{array}$ & $\begin{array}{c}\text { Social influence- } \\
\text { Compliance to social } \\
\text { norms } \\
\end{array}$ & $\begin{array}{c}\text { Cultural } \\
\text { beliefs }\end{array}$ & $\begin{array}{l}\text { Psychological } \\
\text { factors }\end{array}$ & $\begin{array}{c}\text { Social } \\
\text { empowerment }\end{array}$ \\
\hline \multirow{3}{*}{$\begin{array}{l}\text { Performance of } \\
\text { biosocial } \\
\text { projects in } \\
\text { informal } \\
\text { settlements }\end{array}$} & Pearson Correlation & $.487^{* *}$ & $.523^{* *}$ & $.494^{* *}$ & .090 & .144 & $.449^{* *}$ \\
\hline & $\begin{array}{c}\text { Significance level (2- } \\
\text { tailed) }\end{array}$ & .000 & .000 & .000 & .381 & .147. & .000 \\
\hline & $\mathbf{N}$ & 102 & 103 & 101 & 97 & 103 & 101 \\
\hline
\end{tabular}

**. Correlation is significant at the 0.01 level (2-tailed).

*. Correlation is significant at the 0.05 level (2-tailed).

Appendix 2: Elements of Normative action and performance of biosocial projects in informal settlements Model Summary

\begin{tabular}{ccccc}
\hline Model & $\mathrm{R}$ & $\mathrm{R}$ square & Adjusted R Square & $\begin{array}{c}\text { Std. Error of the } \\
\text { Estimate }\end{array}$ \\
\hline & $.601^{\mathrm{a}}$ & .361 & .313 & 8.990 \\
\hline
\end{tabular}

a. Predictors: (Constant) SICF, SIO, SICC, CB, PF, SE,

\begin{tabular}{|c|c|c|c|c|c|}
\hline \multicolumn{6}{|c|}{ ANOVA } \\
\hline Model & Sum of squares & Df & Mean Square & $\mathrm{F}$ & \\
\hline Regression & 3694.010 & 6 & 615.668 & 7.617 & $.000^{\mathrm{b}}$ \\
\hline Residual & 6547.07 & 81 & 80.828 & & \\
\hline Total & 10241.08 & 87 & & & \\
\hline
\end{tabular}

a. Dependent Variable: Performance of biosocial projects in informal settlements

b. Predictors: (Constant) SICF, SIO, SICC, CB, PF, SE,

\begin{tabular}{|c|c|c|c|c|c|}
\hline \multicolumn{6}{|c|}{ Coefficients } \\
\hline \multirow{2}{*}{ Model } & \multicolumn{2}{|c|}{ Unstandardized Coefficients } & \multirow{2}{*}{$\begin{array}{c}\text { Standardized } \\
\text { Coefficients } \\
\text { Beta }\end{array}$} & \multirow{2}{*}{$\mathrm{t}$} & \multirow{2}{*}{ Sig. } \\
\hline & $\mathrm{B}$ & Std. Error & & & \\
\hline Constant & 50.634 & 7.954 & & 6.366 & .000 \\
\hline $\begin{array}{l}\text { Social Influence-Conformity } \mathrm{t} \\
\text { social norms }\end{array}$ & .232 & .330 & .098 & .704 & .483 \\
\hline $\begin{array}{l}\text { Social Influence-Obedience to } \\
\text { social norms }\end{array}$ & .848 & .362 & .287 & 2.342 & .022 \\
\hline $\begin{array}{l}\text { Social Influence-Compliance } \\
\text { to social norms }\end{array}$ & .344 & .271 & .166 & 1.268 & .208 \\
\hline Cultural beliefs & .816 & .300 & .265 & 2.715 & .008 \\
\hline Psychological factors & -.201 & .362 & -.053 & -.556 & .580 \\
\hline Social empowerment & .287 & .216 & .180 & 1.324 & .189 \\
\hline
\end{tabular}

Dependent Variable: Performance of biosocial projects in informal settlements 
Appendix 3: Normative action and performance of biosocial projects in informal settlements

\begin{tabular}{cccc}
\hline & Model Summary & \\
\hline Model & $\mathrm{R}$ & R square & Adjusted R Square \\
\hline & $.586^{\mathrm{a}}$ & .320 & .312 \\
\hline
\end{tabular}

b. Predictors: (Constant) Normative action

\begin{tabular}{cccccc} 
& \multicolumn{2}{c}{ ANOVA } & F & \\
\hline Model & Sum of squares & Df & Mean Square & 40.454 & $.000^{\mathrm{b}}$ \\
Regression & 3276.217 & 1 & 3276.217 & 80.987 & \\
Residual & 6964.863 & 86 & & \\
Total & 10241.08 & 87 & & \\
\hline
\end{tabular}

c. Dependent Variable: Performance of biosocial projects in informal settlements

d. Predictors: (Constant) Normative action

\begin{tabular}{|c|c|c|c|c|c|}
\hline \multicolumn{6}{|c|}{ Coefficients } \\
\hline \multirow{2}{*}{ Model } & \multicolumn{2}{|c|}{ Unstandardized Coefficients } & \multirow{2}{*}{$\begin{array}{c}\begin{array}{c}\text { Standardized } \\
\text { Coefficients }\end{array} \\
\text { Beta }\end{array}$} & \multirow[t]{2}{*}{$\mathrm{t}$} & \multirow{2}{*}{ Sig. } \\
\hline & B & Std. Error & & & \\
\hline (Constant) & 51.821 & 6.257 & & 8.282 & .000 \\
\hline Normative action & .350 & .055 & .566 & 6.360 & .000 \\
\hline
\end{tabular}

Dependent Variable: Performance of biosocial projects in informal settlements

Appendix 4: Summary of Tests of Hypothesis and Results

\begin{tabular}{lllll}
\hline Research Objective & Hypotheses & Results & Table & Remarks \\
\hline $\begin{array}{l}\text { To examine the extent to } \\
\text { which normative action } \\
\text { influence performance of } \\
\text { biosocial projects in }\end{array}$ & $\begin{array}{l}\text { Ho: There is no significant } \\
\text { relationship between } \\
\text { normative action and } \\
\text { performance of biosocial }\end{array}$ & $\mathrm{F}=40.454$ & $\mathrm{P}=0.000<0.05$ & Table 4.9 and \\
Nairobi County, Kenya. & $\begin{array}{l}\text { Table 4.10 } \\
\text { projects in informal } \\
\text { settlements in Nairobi } \\
\text { County. }\end{array}$ & $\mathrm{r}=0.586$ & $\begin{array}{l}\text { Rejected the null } \\
\text { hypotheses. There is } \\
\text { strong relationship at } \\
\mathrm{r}=0.586\end{array}$ \\
& & Adjusted $\mathrm{R}^{2}=0.312$. & & \\
\hline
\end{tabular}

\section{REFERENCES}

[1] Aronson, E., WilsonT.D. \& Akert A.M. (2005).

[2] Baron, R.M. and Kenny, D.A. (1999). The moderator-mediator variable distinction in social psychology research: conceptual, strategic and statistical considerations. Journal of personality and social psychology, 51, $1173-1182$

[3] Cialdini RB, Kallgren CA, Reno RR (2012) A focus theory of normative conduct: A Theoretical refinement and re-evaluation of the role of norms in human behavior. Adv Exp Soc. Psychol 1991, 24:201-234.

[4] Crandall CS, Eshleman A, O'Brien L. (2002): Social norms and the expression and suppression of prejudice: the struggle for internalization. J Pers Soc Psychol 2002, 82:359-378.

[5] Crandall CS, Ferguson MA, Bahns AJ (2013): When we see prejudice: the normative Window and social change. In Stereotyping and Prejudice: Frontiers of Social Psychology. Edited by Stangor C, Crandall CS. Psychology Press; 2013:53-69.

[6] Duvendack, M, et al; 2011, 'What is the evidence of the impact of microfinance on the well-being of poor people?' EPPI-Centre, Social Science Research Unit, Institute of Education, University of London

[7] Frauke Kreuter, Stanley Presser, and Roger Tourangeau. (2008) Social Desirability Bias in CATI, IVR, and Web Surveys: The Effects of Mode and Question Sensitivity. Public Opinion Quarterly, 72(5): 847-865

[8] Gakuu, Kidombo and Keiyoro (2016). Fundamentals of Research methods: Concepts, Practiv and Application. Kenya Aura Publishers.

[9] Gupta, M. C., \& Boyd, L. H. (2008). Theory of constraints: a theory for operations management. International Journal of Operations \& Production Management, 28(10), 991-1012.

[10] Halperin, E., \& Gross, J. (2011). Emotion regulation in violent conflict: Reappraisal, hope, and support for humanitarian aid to the opponent in wartime. Cognition \& Emotion, 25, 1228-1236.

[11] Government of Kenya, (2012). Press release. Government printer.
[12] Kenya National Survey for Persons with Disabilities (2008) Preliminary report available at www.afri-can.org.

[13] Kenya National Disability survey 2008 report.

[14] Kidombo, Gakuu and Keiyoro (2013). Fundamentals of Management: Theories, concepts and Practices. Kenya Aura Publishers.

[15] Leach, L. P. (2012). Critical Chain Project Management Improves Project Performance. Project Management Journal, 30(002), 39.

[16] Leeman J, Baernholdt M, Sandelowski M. Developing a theory-based taxonomy of methods for implementing change in practice. J Adv Nurs.2007; 58:191-200.

[17] Moriya, N. (2008). Noise-Related Multivariate Optimal JointAnalysis in Longitudinal Stochastic Processes in Progress in applied mathematical modeling". In Fengshan Yang. Progress in 224 Applied Mathematical Modeling. Nova Science Publishers, Inc. pp. 223-260. ISBN 978-1-60021-976-4.

[18] Nairobi County Integrated Development plan, NCIDP 2013-2014

[19] Nairobi Cross-sectional Slums Survey (NCSS) 2012, Population and Health Dynamics in Nairobi's Informal Settlements, Nairobi, Kenya.

[20] Nyonje, Kyalo and Mulwa (2012). Monitoring and Evaluation of Development projects and programmes. Kenya Aura Publishers.

[21] Orlikowski W. Improvising organizational transformation over time a situated change Perspective. Inform Syst Res. 1994; 7:63-92.

[22] Pittman, P. H. (1994). Project management: A more effective methodology for the planning and control of projects. Unpublished $\mathrm{PhD}$ Dissertation. Athens, GA: University of Georgia at Athens.

[23] Republic of Kenya (2010). Constitution of Kenya 2010.

[24] Republic of Kenya (2008). Planning bulletin article on disability mainstreaming in policy and planning by the Ministry of State for Planning, National development and Vision 2030.

[25] Saunders M., Lewis P., Thornhill A. (2003). Research Methods for Business Students. Prentice Hall Publishers 3rd Edition.

[26] Shapiro, S. S.; Wilk, M. B. (1965). An analysis of variance test for normality (complete samples). Bimetrika 52 (3-4): 591-611.

[27] Shield, Patricia and Rangarjan, N. (2013). A Playbook for Research Methods: Integrating Conceptual Frameworks and Project 
Management. Stillwater, OK: New Forums Press.

[28] Wallerstein. (1992). Powerlessness, empowerment and Implications for promotion projects. American journal of promotion, 6:197-205

[29] World Bank. 2003. Adolescents and Youth with Disability: Issues and Challenges. International Policy and Program Review with Recommendations. Washington, DC: World Bank. Accessed March 2014.

http://siteresources.worldbank.org/EXTLACREGTOPHIVAIDS/Res ources/Adolescents and Disability Final.pdf WHO/World Bank. 2011 World Report on Disability. Geneva: WHO. Accessed March 9, 2014 http://www.who.int/disabilities/world_report/2011/en/.

[30] Van Zomeren, M., Spears, R., Fischer, A. H., \& Leach, C. W. (2004). Put your money where your mouth is! Explaining collective action tendencies through group-based anger and group efficacy. Journal of Personality and Social Psychology, 87, 649-664. doi:10.1037/00223514.87.5.649.

Ngacha Njeri is a PhD candidate at the University of Nairobi, Pursuing Project Planning and Management. By profession he is a Monitoring and Evaluation Specialist focusing on project implementation tracking indicators and has vast experience on qualitative research, Grant and Proposal writing skills. 